The representation of citizens and monarchy in Acts of

Parliament in 1800 to 2000 : Identifying social roles through collocations

\title{
Lehto, Anu
}

John Benjamins

2019

Lehto , A 2019 , The representation of citizens and monarchy in Acts of Parliament in 1800 to 2000 : Identifying social roles through collocations . in T Fanego \& P Rodríguez-Puente (eds) , Corpus-based Research on Variation in English Legal Discourse . Studies in Corpus pÿLinguistics , no. 91 , John Benjamins , Amsterdam , pp. 235260 . https://doi.org/10.1075/scl.91.10leh

http://hdl.handle.net/10138/326149

https://doi.org/10.1075/scl.91.10leh

acceptedVersion

Downloaded from Helda, University of Helsinki institutional repository.

This is an electronic reprint of the original article.

This reprint may differ from the original in pagination and typographic detail.

Please cite the original version. 


\title{
The representation of citizens and monarchy in Acts of
}

\section{Parliament in 1800 to 2000}

\author{
Identifying social roles through collocations
}

Running head: The representation of citizens and monarchy in acts

Anu Lehto

University of Helsinki

This chapter considers the representation of citizens and the British monarchy in Acts of Parliament from the nineteenth and twentieth centuries in the Corpus of Late Modern English Statutes. The analysis investigates collocates associated with the two social groups and traces their semantic preferences and semantic prosodies. The portrayals of the groups are related to developments in the socio-historical context and legislation.

The study suggests that the acts form notably dissimilar representations of the monarchy and citizens. The Crown is generally addressed in a respectful manner. The role of the citizens, by contrast, improves considerably in the data, i.e. the nineteenth-century acts focus on the criminal actions of the citizens, while their rights are emphasised in the following century.

Keywords: Collocation, representation, Acts of Parliament, Late Modern English, historical pragmatics 


\section{Introduction}

Linguistic expressions carry various meanings and they can also reflect beliefs related to different groups of people. These meanings and associations are shared by the participants in the discourse community and they accumulate over time to form more stable belief systems. Studies on representation focus on revealing such shared assumptions about people and concepts in order to reveal how speakers perceive particular phenomena (Burr 2002: 106). This chapter studies representations in British Acts of Parliament from the nineteenth and twentieth centuries by contrasting the social groups of citizens and the monarch. These two groups can be expected to have been portrayed differently in the acts since the authorities are in a more powerful position, while the citizens are posed obligations and rights, making them the objects of the orders. The role of the citizens is investigated by the headword person, as this general term most often refers to all citizens in the acts, while the status of the monarchy is considered through the headwords king, queen, majesty, crown and sovereign (see Section 7). The analysis of social groups is significant in my data, since there have been only a few previous studies on the portrayals of social groups in historical material (e.g. Bäcklund 
2006) and since earlier research has not considered the representation of officials or lay people in national legislation.

This study uses collocation analysis to consider the representations of social groups, as collocations can reveal meanings associated with words. The assessment identifies groups of collocates with similar meanings, known as semantic preference (Sinclair 2004: 31); collocations can also form more abstract evaluative meanings related to the headword, called semantic prosody (see Section 3). In addition to collocations, this study is based on genre analysis. Genres can form different representations of groups of people depending on the audience and purpose of the texts in question. Consequently, collocates can vary according to genre (see Hunston 2007), and the acts can be expected to form specific representations of the studied social groups which are not necessarily found in other genres. Historical pragmatics is employed in the analysis, as it supports the investigation of historical texts in their context of writing (see Taavitsainen \& Jucker 2015); the material covers two hundred years of legal writing, which provides a diachronic view of the genre.

The roles of the citizens and monarch are worth considering in the historical acts, since Victorian legislation aimed especially to improve the living conditions of the citizens and to assure more equal treatment of people (see Cornish et al. 2010, Rees 2001). The citizens, for instance, became more involved in electing representatives in Parliament and other 
commissions: in the nineteenth century, only a limited group of men was allowed to vote but in 1918 all men irrespective of their status and wealth gained voting rights, and in 1928 all women over 21 were enfranchised (Thane 2010: 12). Further, the rights of workers gradually improved in the era: for instance, in 1847 the maximum allowed working hours of women and children in factories were lowered to 10 hours instead of 12 hours per day. In 1878 child labour was limited by forbidding children under 10 years to work in factories. Additionally, the government started to provide monetary support for education and new schools were established especially in the 1870 s and 1880 s, and education became compulsory for children over five years of age (see Kirby 2003). The role of the poor was affected by several acts such as the Poor Law Amendment Act from 1834, which provided aid for the poor in workhouses, but attitudes towards the poor were nevertheless harsh. Generally, the nineteenth and twentieth centuries saw many improvements in the lives of the citizens, but the living conditions of different groups of people were poor when compared to the contemporary rights of citizens. British society was undergoing many extensive changes such as the industrial revolution and rapid population increase, which affected the living standards of the citizens. This study thus aims to investigate how these developments are reflected in the collocates over the two centuries. 


\section{Representation of social groups and earlier studies}

The concepts of representation and social role refer to identities that are assigned to groups of people by other speakers. Burr (2002: 106) states that the representations are assumptions which are shared in the discourse community. The roles are typically not recognised by the speakers themselves, but these unconscious beliefs strongly affect how different social groups or other phenomena are perceived in the community. Social groups are also studied in other fields such as in (historical) sociolinguistics (see e.g. Pahta et al. 2010). However, sociolinguistic studies are mainly interested in how individual speakers form their identities and they relate the speaker's linguistic choices, for instance, to the speaker's age and other sociolinguistic variables. Studies on representation, in contrast, encompass numerous speakers and aim to reveal which categorisations are collectively linked with particular groups of people (see Baker 2014: 74). The latter view is adopted in my study, as the analysis does not assess the linguistic choices of individual language users but uncovers the collective associations of the citizens and monarchy that emerge in institutional writing. The representations are created through repetition in the discourse community and they do not reflect personal associations or attitudes towards people. In this sense the 
representations are close to cultural stereotypes (Stubbs 2001: 215). Fairclough (1992: 89) discusses the formation of meanings and ideologies; he states that they are the result of past events and that these meanings are constantly reproduced and naturalised in new communicative situations. The beliefs become more established through repeated communication, and repetition is also central in the analysis of representations through collocations, as only those collocates are considered that recurrently appear near the headwords (see Section 3).

The representations of the citizens and authorities have not been assessed in earlier research. The studies on representation generally encompass present-day data, but there are some previous accounts of social groups in historical material. The studies in present-day data typically approach representation from the point of view of critical discourse analysis or gender studies and many of these assessments use collocation analysis. Baker \& McEnery (2005), for instance, rely on critical discourse analysis and collocations to trace the role of refugees and asylum seekers in British newspapers and in documents by the Office of the United Nations High Commissioner for Refugees (see also Gabrielatos \& Baker 2008, McEnery et al. 2015). Within gender studies, Pearce (2008) investigates collocates related to men and women in various genres, and Norberg (2016) retrieves collocates linked with boys and girls in a webbased corpus (see also e.g. Sigley \& Holmes 2002, Baker 2014). Focusing 
on historical material, Gupta (2015) examines the women's suffrage movement in The Times in 1908-1914, noting that the newspaper reports its activities in a negative light. Further, Bäcklund (2006) studies the role of women by analysing modifiers in nineteenth-century genres such as in fiction (see also Sveen 2010). Finally, McEnery (forthcoming) investigates the representation of the criminalised poor in the seventeenth century in Early English Books Online (EEBO) by using collocation analysis, and notices that various types of criminalised poor are portrayed differently, e.g. rogues are considered more active and deceitful, while beggars are seen as lazy.

\section{Collocation analysis}

The study employs corpus linguistic methods and takes advantage of collocation analysis. Collocations reveal lexical elements that appear together more often than random word combinations (Sinclair 1991: 115, Stubbs 2002; see also Baker 2016, Gries 2013 and Xiao 2015 on statistical methods). The collocations can form adjacent word strings or merely exist near each other within a certain span from the headword or node (Sinclair 1991: 115). The span has ranged at least from two to five words in earlier studies, although many analyses have used the span of four or five words, 
indicating that the collocates need to appear up to four or five words to the left or right from the node. Sinclair et al. (2004: 13), for instance, state that the span of four words encompasses significant collocates (see also Sinclair 1991: 170, McEnery \& Hardie 2012: 129). The analyses on representation have often relied on the span of five words (e.g. Gabrielatos \& Baker 2008), and this span is similarly used in the present analysis (see Section 6 on methods). The wider span is especially useful in legal language, since this genre often combines, for instance, hyponyms, synonyms and antonyms by binomials and multinomials with the conjunctions and and or (e.g. person or persons), which pushes other collocates further from the node (see Lehto 2017). Additionally, numbers that organise the texts or point to subjections, for instance, are common in the genre, affecting the types of collocations within the space of the node.

Collocations are significant from the semantic point of view, since they have an effect on the meaning of the headword (e.g. McEnery \& Hardie 2012, Sinclair 1991, Stubbs 2002). I take advantage of this realisation in my analysis, since the aim is to trace associations related with the headwords. The focus is not, however, on individual collocates but on larger semantic and functional categories of collocation. Sinclair (1991: 112) notices that "[m]any uses of words and phrases show a tendency to occur in a certain semantic environment". The node often attracts collocates which are related in meaning, although individual 
collocates also affect the node. Consequently, Sinclair (2004: 31-33) discusses words as units of meaning and explains that meaning is shaped by five different phenomena, i.e. core, colligation, collocation, semantic preference and semantic prosody. Sinclair uses the phrase naked eye to illustrate the construction of meaning. Hence, the core is the basic and non-metaphorical meaning of lexical items, while the other types are more abstract phenomena, ranging from the more concrete to the most abstract types. Colligation points to grammatical classes that appear with a lexical item such as the prepositions by and from, which often precede the phrase naked eye. Semantic preference refers to groups of collocates that are similar in meaning, e.g. in my material, the word person often collocates with frauds and assault, which denote offences. Finally, semantic prosody recognises evaluations that are linked with a certain node, i.e. Sinclair's example naked eye denotes difficulty. The associations are examined within the context of the node: "the semantic prosody has a leading role to play in the integration of an item with its surroundings" (Sinclair 2004: 34). Sinclair's examples indicate that this concept does not merely recognise positive or negative attitudes linked with the node, but the evaluation relies on pragmatic analysis of the node and its collocates in their context (see also Hunston 2007, McEnery \& Hardie 2012: 138, Partington 2004). My analysis considers semantic preference and semantic prosody in particular: the collocates are grouped into semantic categories 
according to their topic, examining the associations emerging from the corpus.

The collocations can change diachronically, posing varying semantic preferences and semantic prosodies at different points of time. Some earlier studies have drawn attention to the diachronic assessment of collocations. Gabrielatos \& Baker (2008: 11) acknowledge the difference between consistent and seasonal collocates: consistent collocates remain in use in the studied texts over the corpus timeline, while seasonal collocates emerge and decline over a limited period, such as in specific issues of newspapers. Gabrielatos \& Baker state that consistent collocates are more important in revealing the meanings of headwords, as they persist over longer periods of time. McEnery (forthcoming) makes a more detailed distinction between collocates on the basis of their diachronic status, by differentiating between consistent, terminating, initiating and transient collocates. Consistent and transient collocates correspond to Gabrielatos \& Baker's consistent and seasonal collocates, and McEnery additionally notes that transient collocates often reflect brief debates over a certain topic. Further, terminating collocates disappear from use in the corpus, while initiating collocates acquire a novel meaning, when the meaning of the headword changes. In my analysis, the data is divided into hundredyear time periods, and hence it is possible to trace diachronic changes of collocates, paying attention to consistent, initiating and terminating 
collocates. However, this division does not allow a detailed analysis of seasonal collocates, as the data is not categorised into shorter time periods.

\section{Genre studies and historical pragmatics}

Genre is here understood as a set of extra-linguistic features, such as the purpose and audience of the texts, that affect the compilation and reception of the documents (see e.g. Taavitsainen 2015). Genre differs from the concept of text type, which refers to text-internal linguistic features such as the use of passives. Genres and repeated linguistic expressions emerge when speakers participate in similar communicative situations that have the same purposes (Croft 2000). Hoey (2005: 5) states that words activate collocations and patterns in speakers' minds from previous encounters, resulting in repeated constructions and specific genre conventions. From the point of view of genre, the purpose of the acts is to control the actions of the citizens. The acts are authoritative and institutional texts aimed at less powerful recipients, and they are notably formal and impersonal in their linguistic expressions. The audience is wide, but the actual readers of the acts are mostly other legal professionals. Additionally, the public acts discuss the citizens on a general level, i.e. the texts do not make references to individual persons, although they often refer to specific officials. The 
acts are generally formulaic texts and repeat specific lexical strings, e.g. the enacting formula is stated in each act (Lehto 2015). Repetition increases the prestige of the documents and ensures that the wordings are successfully formulated to make them legally binding, which affects the types of collocates found in the data.

Words gain different collocations in genres, resulting in various meanings and associations. Partington (2004: 153) suggests that semantic prosodies are genre specific; he points out that newspapers are more likely to publish criminal and negative news, causing the semantic prosodies of words to be negative in this genre. Hunston (2007) similarly notices that semantic prosodies vary, as only some meanings emerge in a single genre. Thus, the semantic prosody is not a feature of the word as such, but words gain specific discourse functions in particular genres. Repeated portrayals within genres can further diffuse to novel contexts. The acts reveal representations of the citizens in legal language but at the same time they can be expected to partially reflect the social roles of citizens in the whole of society. The acts can additionally form novel associations about the citizens that enter other genres, especially since the documents affect the status of persons, for instance by improving their rights.

The term genre focuses on repeated communication that triggers the use of certain linguistic expressions. However, genres are also dynamic, as they need to adapt to changing communicative situations. The collocations 
and representations can become different in time, and the field of historical pragmatics acknowledges the diachronic approach to genres. Taavitsainen \& Fitzmaurice (2007: 13) state that historical pragmatics assesses "language use in past contexts and examines how meaning is made." Historical pragmatics often uses corpus linguistic methods and scrutinises authentic data in its socio-historical contexts (see also Taavitsainen \& Jucker 2010). Historical pragmatics has been traditionally divided into pragmaphilology and diachronic pragmatics; both approaches study texts firmly in their context of writing, but the former is synchronic, while the latter focuses on diachronic analysis (Jacobs \& Jucker 1995: 10). Diachronic pragmatics includes diachronic form-to-function mapping and diachronic function-to-form mapping, of which the former considers linguistic expressions and defines their function, while the latter takes certain functions such as speech acts as the starting point and analyses their realisations in genres. The analysis of collocations corresponds to diachronic form-to-function mapping, as the collocations are automatically retrieved from the corpus and their functions are considered from the point of view of semantic preference and semantic prosody. The lives of the citizens were improved in the era, and the analysis studies the collocates within these changes in the socio-historical context. The collocations further reveal developments in legal writing, which became more organised (see Section 10). 


\section{Data: Corpus of Late Modern English Statutes}

The dataset is a self-compiled diachronic corpus titled the Corpus of Late Modern English Statutes, and the database includes Acts of Parliament published between 1800-2000. The texts have mainly been retrieved from online sources of the National Archives of the UK government, which contains all acts published after 1988, and a partial dataset of acts issued in 1801-1987. Additional texts were included from printed works to increase the variety of topics in the corpus due to the limited number of acts available in the archive, especially from the beginning of the nineteenth century. The acts were chosen on the basis of their topic, focusing on social issues. The data covers different layers of the citizens, e.g. the corpus contains acts on the poor, status of children, women, employees, employers and vagabonds. Additionally, the acts concern governmental issues such as collecting of taxes and expressing loyalty to the king. Some individual examples of the corpus texts include enactments on social security and offences such as the National Health Services Act from 1946 and Offences Against the Person Act from 1861. Additionally, the rights of the monarch and officials are addressed, for instance, in the Crown Proceedings Act (1947) and in His Majesty's Declaration of Abdication 
Act (1936); the former act made it lawful to sue the Crown in the courts of law and the latter refers to the abdication of King Edward VIII and the succession of King George VI to the crown. The compilation of the corpus was begun by inspecting all titles of acts in the National Archives, and additionally I ran lexical searches to locate acts that concern social groups. Previous works on the socio-historical context and historical legislation were crucial to the text selection in order to identify important issues concerning the citizens and the Crown.

The corpus contains in total about 290,000 words distributed evenly over the nineteenth and twentieth centuries. The number of separate acts in the corpus is 68 , and 34 acts are included from both centuries, as is illustrated in Table 1.

Table 1. Word count in the Corpus of Late Modern English Statutes

\begin{tabular}{cccc} 
& 19th century & 20th century & Total \\
\hline Word count & 145,376 & 144,074 & 289,450 \\
\hline Number of acts & 34 & 34 & 68 \\
\hline
\end{tabular}

Most of the texts could be copied in text format from the online archive but a number of acts were additionally typed in since text versions were not available for all statutes. The texts were proofread against the original source texts found in the archive. The corpus texts were taken from the beginning of the acts excluding prefatory material such as tables of contents. Many of the acts are rather extensive in their word count but only 
the first 5,000 words were included from each act in order to increase the variety of acts in the data and to compile a corpus with a balanced number of words from each act. Some acts were included whole, as they do not exceed the word limit. The shortest act in the corpus is the Witnesses Act from 1806, which comprises 263 words; the act enacts that witnesses must answer questions posed to them in court even though the answers would put them at risk of civil liability.

\section{Method of analysis}

The collocations were assessed with the corpus software AntConc (Anthony 2014). The span of collocation was set to five words from the headword. As mentioned above (see Section 3), a lower span would be especially problematic in this genre, as it would likely retrieve mainly binomials and multinomials typical of historical acts (e.g. city, town or borough). Further, numbers written in numerals were not counted as collocates since legal documents use abundant numbering and referencing to specific parts of the acts, which could affect the number and type of other retrieved collocates; numbers that were spelled out were, however, included in the analysis, as they are not used in the organisation of the documents. The frequency threshold was set to three in both centuries, i.e. 
collocates must appear at least three times to be considered collocates. This threshold corresponds to the frequency of approximately 2 per 100,000 words (or 21 per million words) in both centuries.

The headwords that refer to the citizens and the Crown were collected from a wordlist generated from the corpus. The headword person was used to analyse the role of the citizens, as it is the most common reference to the inhabitants; the word citizen, for instance, is rare in the data. The role of the monarch is examined by using the headwords king, queen, crown, sovereign and monarch. In addition to the lemma forms, the plural and genitive forms were included in the analysis. The data was split into two datasets, i.e. acts from the nineteenth and twentieth centuries, to analyse the collocates diachronically. The assessment comprises only content collocates and excludes grammatical words, since the purpose was not to concentrate on grammatical changes. The collocates retrieved by AntConc were extracted to Excel and I sorted content collocates manually from this list. The investigation retrieved 1,199 content collocate types. The collocates were then categorised according to their topics by analysing them in the context of the concordance line and often within a larger textual context. The changes in semantic prosody and semantic preference were further evaluated within a broader socio-historical context. 


\section{Overview of the frequencies of different social groups}

The words denoting the citizens and the monarchy were first inspected in order to gain an overview of their frequencies in the two centuries. The words that refer to the citizens are notably more common in both centuries than those that refer to the sovereign; hence, the focus of the acts is on the inhabitants and not on the monarch. There are in total 1,966 instances of the 6 studied headwords (including the plural and genitive forms) in the nineteenth century and 1,701 in the twentieth century. The normalised frequencies decline in the latter century from 1,352.4 to $1,180.6$ instances per 100,000 words, as can be seen in Table 2 .

Table 2. Frequencies of words referring to social groups in the 19th and 20th centuries

\begin{tabular}{lcccc} 
& \multicolumn{2}{c}{ 19th-century acts } & \multicolumn{2}{c}{ 20th-century acts } \\
& Raw freq. & F./100,000 & Raw freq. & F./100,000 \\
\hline person & 1,311 & 901.8 & 1,566 & $1,086.9$ \\
majesty & 426 & 293.0 & 69 & 47.9 \\
king & 119 & 81.9 & 21 & 14.6 \\
queen & 61 & 42.0 & 17 & 11.8 \\
crown & 41 & 28.2 & 28 & 19.4 \\
sovereign & 8 & 5.5 & 0 & 0 \\
Total & 1,966 & $1,352.4$ & 1,701 & $1,180.6$ \\
\hline
\end{tabular}

Although the overall frequencies decline, the references to the two social groups indicate distinct developments. Words denoting persons increase, 
while references to the monarch decline in the latter century. Hence, the frequency of the words majesty, king, queen, crown and sovereign decrease from 655 instances to 135 , which corresponds to the normalised frequencies of 450.6 in the former era and 93.7 in the twentieth century. All of the words denoting the sovereign become diachronically less numerous, and there are no instances of sovereign in the twentieth century. The monarch is most often referred to by the expression majesty; in addition, king and queen are typical expressions in the nineteenth century but the term crown is the second most common referent in the twentieth century; the word crown can be seen as a more neutral term, which does not refer to the king or queen as an individual but to the whole sovereign. ${ }^{1}$ In general, both social groups of citizens and the monarch are treated in the acts of both centuries, and the role of the citizens in particular prevails in the acts, while the importance of the Crown lessens towards the twentieth century.

1 The word monarch does not occur in the material. In addition to the word person, there are instances of people, inhabitant, citizen and subject. The word people is found 5 times in the nineteenth century and 13 times in the latter century but it mostly appears as part of titles denoting the Representation of the People Acts. The word citizen appears 4 times in the nineteenth century in the same act, while there are 3 occurrences from one act in the twentieth century. The expression inhabitant is repeated 33 times in the nineteenth century and twice in the later era but it most often refers to people inhabiting buildings. The instances of the word subject are mostly used with other meanings (e.g. be subject to), and subject appears 15 times as part of the expression majesty's subject(s) in the nineteenth century and 4 occurrences of British subject are found in the twentieth century (see further Section 10). 


\section{The representation of the citizens: person}

The citizens are most often referred to by the word person, and consequently it attracts the highest number of collocates for the analysed headwords. There are altogether 992 content collocate types in the acts, and 467 stem from the nineteenth century and 525 from the twentieth century. ${ }^{2}$ The raw numbers and also normalised frequencies indicate that the number of collocates increases towards the latter century from 321.2 to 364.4. This development follows the frequencies of the word person, which becomes more numerous in the data (see Section 7). The most common collocates in the nineteenth century are shall, act and may, while in the twentieth century the collocates young, child and section are the most often repeated. The fifteen most common content collocates in both centuries are indicated in Table 3.

Table 3. Top content collocates for person in the 19th and 20th centuries

\begin{tabular}{cccc}
$\begin{array}{c}\text { 19th century } \\
\text { Number of } \\
\text { collocates }\end{array}$ & Collocate & $\begin{array}{c}\text { 20th century } \\
\text { Number of } \\
\text { collocates }\end{array}$ & Collocate \\
\hline 342 & shall & 206 & young
\end{tabular}

2 Including grammatical collocates, there are altogether 896 collocate types with 12,815 collocate tokens in the nineteenth century and 912 collocates with 15,167 tokens in the twentieth century. 


\begin{tabular}{cccc}
63 & act & 131 & child \\
62 & may & 121 & section \\
54 & employed & 111 & act \\
45 & enacted & 82 & care \\
44 & young & 69 & children \\
40 & convicted & 65 & age \\
34 & case & 52 & respect \\
34 & provided & 47 & employed \\
33 & child & 46 & offence \\
33 & property & 44 & authority \\
32 & said & 43 & subjection \\
29 & entitled & 41 & employment \\
27 & guilty & 35 & relation \\
26 & unlawfully & 32 & purposes \\
\hline
\end{tabular}

The words young, child, act and employed appear among the most numerous collocates in both centuries. However, the top content collocates already indicate that the topics of the collocates differ diachronically in the data. In the earlier century, the focus of the most frequent collocates is on general legal actions (shall, may, enacted, provided) and crime (convicted, guilty, unlawfully), while in the twentieth century the attention shifts to the wellbeing of the citizens and especially to children (care, children) and legal documents (section, subjection).

The collocates from both centuries were categorised according to their topics, which generated thirteen classes. These topics deal, for instance, with legal actors, crime and legal language:

1. Legal actors (authorities) (e.g. court, commissioners)

2. Legal language/processes (e.g. section, appoint, law)

3. Actions (e.g. appear, removing, kept) 
4. Crime and punishment (e.g. murder, conviction)

5. Work (e.g. apprentice, factory)

6. Possessions (e.g. property, goods)

7. Welfare (e.g. health, safety, benefit)

8. Relation to groups of people (e.g. rogues, woman)

9. Type of person (e.g. idle, unsound)

10. Number (e.g. two, one, sixteen)

11. Time (e.g. year, hours)

12. Location (e.g. Ireland, Scotland)

13. Collocates that show two or more of the topics (e.g. case)

The first three topics centre on legal actors and processes, i.e. legal actors encompass authorities such as commissioners; collocates pointing to legal language include, for instance, references to sections of law, legislative expressions and processes; and finally, collocates that describe actions are more neutral descriptions of activities. The next four topics (numbers 4-7) point to specific themes including collocates discussing crime and punishment, employment, possessions and collocates referring to welfare. 
In addition, there are collocates that relate the word person to other groups of people such as women, and some collocates define the type of person more carefully, such as unsound and idle person. The collocates further include numbers as well as references to time and location (numbers 1012). Finally, the last category (number 13) encompasses overlapping topics, as some collocate tokens refer to more than one theme, e.g. case can express crime and punishment or employment depending on the context.

The distribution of some of the topics is rather similar in both centuries, while other issues show considerable diachronic differences. Figure 1 compares the frequencies of the topics of the collocates in both centuries. 


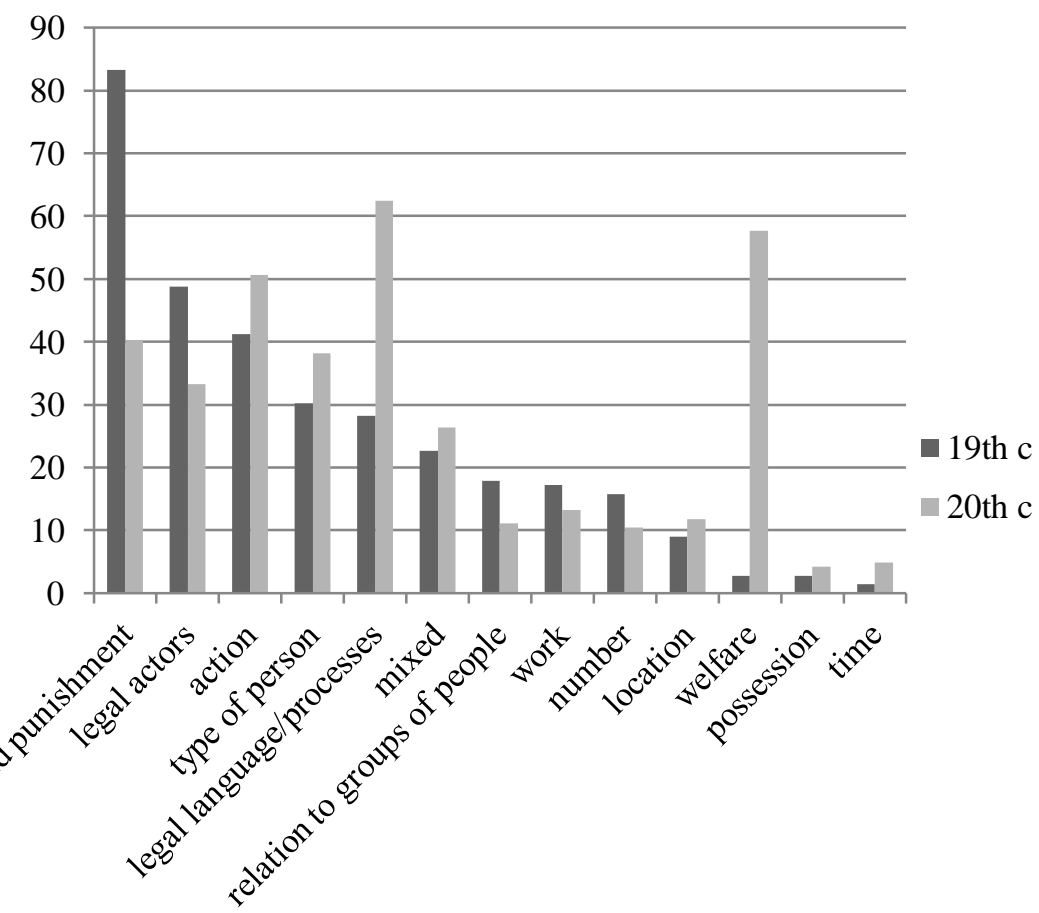

Figure 1. Distribution of the topics of collocates for person in the 19th and 20th centuries (f./100,000 words)

The collocates in the nineteenth-century data most often concentrate on the topic of crime and punishment with the frequency of 83.2. In addition, legal actors (48.9) and legal actions (41.3) are frequently found. In the following century, the most repeated topics are collocates denoting legal language/processes and collocates that concern welfare, with the frequencies of 62.5 and 57.6, respectively; actions (50.7) are typical of the acts in this century as well. Some of the collocates, such as those that relate to possessions and time, are equally rare in both centuries, but none of the topics completely disappears or initiates in the latter century. In general, however, the collocates indicate that the nineteenth-century acts 
represent the citizens as being mainly involved with crimes and being punished for their offences, while in the twentieth century the inhabitants are considered from the point of view of welfare. Further, the twentiethcentury acts are more concerned with legal processes and specific text referencing.

The collocates that centre on crime and punishment are hence most frequent in the nineteenth-century acts. These instances encompass various collocates such as frauds, punishment and offender. The acts portray the citizens both as committing crimes but also as the objects of offences, as is shown in examples (1-2) (the collocates referring to crime and punishment are italicised):

(1) Where any person is convicted of an assault on any constable (1871 Prevention of Crime Act)

(2) Whosoever shall unlawfully... to do some grievous bodily Harm to any Person, shall, whether any bodily Injury be effected or not, be guilty of Felony... (1861 Offences against the Person Act)

In cases, where the word person occurs as an object, the actor is named by another general title such as whosoever, all persons or some more specific 
reference, depending on the topic, to avoid repetition. The word whosoever is used in example (2) to refer to the person committing the bodily injury.

The collocates that point to legal actors and actions are further related to the topic of crime, as they link persons committing offences with the authorities, especially in the nineteenth century. The legal actors include, for instance, the collocates justice, commissioner, constable, members, magistrate, council, churchwardens, authority, officer and parliament. Examples (3-4) illustrate the collocates Justices and constable. it shall be lawful for the Police Magistrate or Justices before whom any Person shall be taken (1845 Gaming Act)

A constable may arrest a person without a warrant (1956 Sexual Offences Act)

The authorities are admitted permissions to take action in cases of illegal deeds by the verb phrases it shall be lawful and may, i.e. the legal actors are given the right to punish and control the actions (i.e. crimes) of the citizens. In example (4), the expression Police Magistrate also appears among the collocates for person, but in the example it falls outside the scope of five words stemming from the node. 
The topic of welfare rarely emerges as a theme within the collocates of the early acts but in the latter century it becomes an important topic. These collocates encompass, for instance, accommodation, health, medical, housing, welfare, safe, education and right. Welfare is often provided for children in the acts and the word person regularly attracts the collocate young in the form young person. Young persons are offered nurturing and the collocate education is common, since schooling became more important in the era. The concordance lines (5-7) show examples of the topic of welfare in the twentieth-century acts. Children and young persons in need of care, protection or control (1963 Children and Young Persons Act)

(6) in providing medical benefit and sanatorium benefit for such persons and the cost of the (1913 National Insurance Act)

(1) A person discriminates against a woman in any circumstances relevant for the purposes of any provision of this Act if-(1975 Sex Discrimination Act)

Example (6) illustrates how the state takes responsibility for the general welfare of the citizens and provides accommodation as well as health care; 
additionally, words that refer to different types of monetary support begin to appear as collocates. The distribution of the collocates that refer to wellbeing reflect the increase of acts on social topics in the twentieth century; this development is noticeable in the corpus, as these acts are more numerous in the latter part of the corpus timeline. Although the citizens are rarely associated with the topic of welfare in the nineteenth century, there are acts on this subject from this era in the corpus, such as the Public Health Act from 1848 and the School sites Act of 1844. The act on public health, however, does not discuss the role of the citizens but focuses on persons as board members, for instance. A notable new collocate in the latter century is discrimination and other similar collocates (see example 7), as the legal equality of people independent of their gender, background or position becomes notable.

The topic of legal language and processes becomes significant in the twentieth-century acts because the texts increasingly make reference to other parts in the same document or refer to wordings in previous acts. In examples (8-9), the collocates section and subsection form links to specific parts in the act, and paragraph is used for the same purpose, although it does not fit the span of five words in the example.

(8) (2) This section shall apply to persons in Ireland with (1913 National Insurance Act) 
(9) passed under paragraph (b), (c) or (d) of subsection (1) above, unless the person whose (1980 Child Care Act)

The first example (8) begins with numbers and the documents use visual cues such as tabulation to organise the acts into numbered parts. This change made it possible to make detailed references to specific parts of the documents. The development of the collocates suggests that in the nineteenth century, the citizens are mainly controlled by legal authorities, while in the twentieth century the actions of the citizens are increasingly administered by specific parts of legal documents and legal processes.

The collocates that describe persons further indicate some diachronic differences. The twentieth-century collocates define persons according to their age, marital status, place of habitation and occupation, such as being a tenant. The nineteenth-century acts, however, are more varied in their descriptions and form more evaluative categorisations of people on the basis of concepts such as vagrancy, state of mind, poverty, religion, marital status, gender and place of habitation, e.g. idle, disorderly, lunatic, Jewish, unsound, poor and idiot. Example (10) is from the twentieth century and extracts (11-13) from the nineteenth century. 
(10)

...any such byelaws may distinguish between persons of different ages and sexes (1933 Children and Young Persons Act)

(11) VII. And whereas there may be divers poor Persons having or claiming to have a Right, (1838 Dean Forest Act)

(12) ...any Person herein-before described to be an idle and disorderly Person, or a Rogue and Vagabond (1824 Vagrancy Act)

(13) ...word "lunatic" shall be construed to mean any person found by inquisition idiot, lunatic, or of unsound mind, and incapable of managing himself or his affairs (1871 Lunacy Regulation Act)

The nineteenth-century examples include many categorisations of people that would be considered offensive in the twentieth century, such as idiot, lunatic or disorderly person. In general, attributive adjectives and relative clauses are regularly used in the acts to specify the word person: example (12) narrows down the general term person by using the attributive adjectives idle and disorderly to single out the groups of people that the 
law concerns. The extract also encompasses the binomial construction Rogue and Vagabond, as they are included within the groups of people that the law concerns. In general, the collocates that relate person to other groups of people are more numerous in the nineteenth century. In the twentieth century, the collocates relating to the topic of groups of people mainly establish family relations including children, parents, wife and husband, while the nineteenth-century documents relate persons also to women, slaves, children, Quakers, landlords and masters in addition to family members.

\section{The representation of the monarchy}

References to the monarchy are more common in the nineteenth century, and consequently the collocates for majesty, king, queen, crown and sovereign are more numerous in this era than in the latter century. The five headwords studied retrieve 207 collocates altogether. The highest number of collocates is found for majesty in both datasets, as this word is most frequently used to refer to the monarch in the corpus (see Table 1). Table 4 illustrates the distribution of the collocates for each node.

Table 4. Number of collocates for monarch in the nineteenth and twentieth centuries (raw frequencies)

Node Number of collocates 


\begin{tabular}{lcc}
\hline & 19th century & 20th century \\
\hline majesty & 119 & 19 \\
king & 22 & 5 \\
queen & 18 & 6 \\
crown & 13 & 4 \\
sovereign & 1 & 0 \\
Total & 173 & 34 \\
\hline
\end{tabular}

The collocates for king and queen are the second and third most numerous in the data. In total, the collocates are over five times more common in the nineteenth century, adding up to 173 instances. The normalised frequencies of all collocates is about 109 in the nineteenth century and 20 in the twentieth century.

The most frequent collocates for each node display many similarities across the two centuries. The headword majesty, for instance, retrieves the collocates king, excellent, advice and queen among the ten most common collocates in both centuries, as is indicated in Table 5 .

Table 5. Top content collocates for majesty in the 19th and 20th centuries

\begin{tabular}{cccc}
\multicolumn{2}{c}{$19^{\text {th }}$ century } & \multicolumn{2}{c}{$20^{\text {th }}$ century } \\
Freq. & Collocate & Freq. & Collocate \\
\hline 84 & reign & 31 & advice \\
80 & king & 31 & excellent \\
73 & late & 17 & king \\
60 & intituled & 15 & queen \\
52 & excellent & 9 & council \\
41 & george & 9 & may \\
39 & advice & 7 & abdication \\
38 & queen & 5 & declaration \\
38 & said & 5 & right \\
37 & present & 4 & stationery \\
\hline
\end{tabular}

The most repeated collocates for majesty in the nineteenth century are reign, king and late, while excellent, advice and king prevail in the latter 
period. The collocates, such as excellent and advice, that stem from the enacting clause, which is stated in each act, are common, and they are used in both centuries. ${ }^{3}$

The collocates for the monarch were categorised according to their topic, and this assessment generated nine themes. Many of the topics are similar to those found for the word person including the categories of legal language/processes, legal actors, time, actions and mixed collocates, while novel themes include references to the king, praise, possessions and references to the citizens. The distribution of the topics is indicated in Figure 2.

${ }^{3}$ The enacting clause in the Representation of the People Act from 1867, for instance, is as follows: "Be it enacted by the Queen's most Excellent Majesty, by and with the Advice and Consent of the Lords Spiritual and Temporal, and Commons, in this present Parliament assembled, and by the Authority of the same, as follows:" 


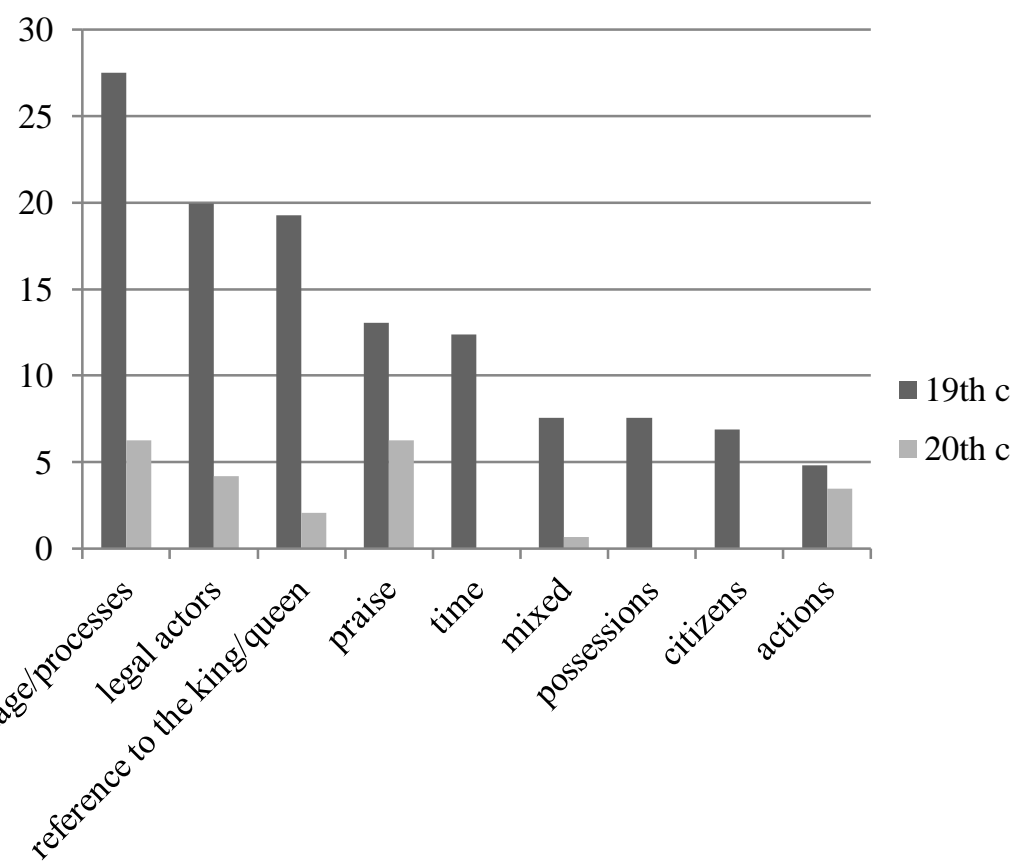

Figure 2. Distribution of the topics of collocates for monarch in the 19th and 20th centuries (f./100,000)

In the nineteenth century, the topics of legal language/processes, legal actors, references to the king or queen and praise prevail, while praise, legal language/processes, and legal actors and actions are most common in the latter century. The distribution of the topics is affected by formulaic expressions used in legal writing: in the twentieth-century acts, the collocates appear mainly in the enacting formula and other references to the Crown are rare. The topic of praise is common in both centuries, and many of these expressions again originate from the repeated enacting clause. Some formulaic expressions of praise from the nineteenth-century acts include the collocates please, god, long, preserve, honour and dignity such as in may it therefore please Your Majesty that..., during the Life of Her present Majesty (whom God long preserve), and for the support of the 
Honour and Dignity of the Crown (1837 1 and 2 Vict Civil List Act). The collocate excellent appears in formulaic expressions in both centuries, e.g. be it therefore enacted by the King's/Queen's most excellent majesty.

In general, however, the monarch is a much more central figure in the nineteenth-century acts, surfacing especially through collocates referring to praise, time, possessions and citizens. Hence, the nineteenthcentury acts emphasise the authority of the monarch through possessions, including places and the military forces such as the collocates dominions, land, forests and naval forces. These concepts are expressed by the genitive case, e.g. Her Majesty's military or naval forces. In addition, the citizens are regularly viewed as possessions of the monarch including the collocates subject(s) and person, such as in for the Relief of Her Majesty's Subjects professing the Jewish Religion (1866 Parliamentary Oaths Act). Further, the central position of the monarch surfaces through the collocates related to time, since in the nineteenth-century acts it is calculated in relation to the ruling years of the queen or king. The collocate year is repeated in the nineteenth-century documents such as in the said recited Act made in the Twenty-seventh Year of the Reign of Queen Elizabeth (1822 Riotous Assemblies Act).

The topic of praise is notable in the earlier acts in the corpus. Example (14) is from the Civil List Act of 1837 that granted money for the expenses of the monarchy of Queen Elizabeth. In addition to collocates 
referring to praise, all expressions of admiration are italicised in the example.

(14) Your Majesty felt confident that Your faithful Commons would gladly make adequate Provision for the Support of the Honour and Dignity of the Crown: Your Majesty's most dutiful and loyal Subjects, the Commons of the United Kingdom..., with Hearts full of the warmest Duty and Gratitude, are desirous that a certain and competent Revenues for defraying the Expences of Your Majesty's Household, and supporting the Honour and Dignity of the Crown of the United Kingdom, during Your Majesty's Life (which God long preserve), may be settled upon Your Majesty, as a Testimony of our unfeigned Affection to Your sacred Person, by whose happy Succession to the Throne Your Majesty's Subjects have the strongest Assurance that the Religion, Laws, and Liberties of this Realm will be continued, and that Your Majesty's said Subjects and their Posterity may, through the Divine Goodness, enjoy every Blessing under Your Majesty's auspicious Reign, have therefore freely resolved to grant unto You, our most 
Gracious Sovereign Lady Queen Victoria... (1837,

Chapter 2, 1 and 2 Victoria, Civil List Act, pp. 6-7)

The extract justifies why monetary support is allowed to the Crown. The actual enactment is rather brief at the end of the extract (have therefore freely resolved to grant unto You), as the focus is on the Commons and the whole nation expressing loyalty to the queen. The queen is addressed in the extract by expressions such as Your Majesty, and other overt expressions of praise include the phrases Your faithful Commons would gladly..., with Hearts full of the warmest Duty and Gratitude and as a Testimony of our unfeigned Affection to Your sacred Person. Additionally, formulaic declarations of praise can be found such as Your Majesty's Life (which God long preserve). The extract further considers persons as possessions as in Your Majesty's Subjects.

\section{Discussion and conclusions}

The assessment of the collocates indicated that the acts mainly deal with issues concerning the citizens, while the monarch is addressed noticeably less frequently. The overall normalised frequency for person in the corpus is considerably higher (994 per 100,000 words) than for the words majesty, 
king, queen, crown and sovereign (273). These occurrences are reflected in the number of collocates retrieved from the corpus, the word person attracting 992 content collocates, followed by majesty with 138 collocates. The number of collocates further indicates diachronic changes, as the collocates for person increase from 467 instances (normalised frequency of 321 ) in the nineteenth century to 525 occurrences (normalised frequency of 364) in the twentieth century, and similarly the numbers of the word person become higher in the latter century. The references for the monarch, in contrast, are lower and decrease diachronically in the acts. The decline is affected by a change in the referencing style, as the earlier acts in the corpus identify other acts by referring to the ruling year of the king, while later documents use more specific referencing (see below). The development also reflects changes made to the authority of the monarch and other authorities in the era analysed, e.g. the Crown Proceedings Act (1947) gave citizens the right to sue the Crown in court (see McLean 2012: 226). In addition, the idea of a nation-state which is separate from the king or queen developed in the era, causing personalised references to the rulers to become less numerous.

The distribution of the collocates for person indicates considerable changes to the representation of citizens in the late modern period. The collocates were categorised according to their semantic preference, and in general, the citizens are portrayed from twelve different viewpoints such as 
their relation to the authorities and other groups of people, legal processes, actions and types of persons. In the nineteenth century, the citizens are mainly seen as committing crimes or being punished for their offences. Thus, the nineteenth-century collocates mostly accord the semantic prosody of trouble to the word person, i.e. the acts generally view the citizens as causing problems in society. In the twentieth century, the ideas of welfare, discrimination and equality become important, and the collocates health, discrimination and welfare, for instance, can be recognised as initiating collocates regularly found in the twentieth-century acts. Hence, instead of representing the citizens as troublemakers, their wellbeing and safety are underlined. Consequently, the semantic prosody is more positive and focuses on wellbeing. McLean (2012: 114) summarises that the twentieth century saw the rise of the welfare state. In the nineteenth century, the Poor Laws allowed relief to the poor, but this aid was local and often stigmatised. Additionally, numerous voluntary societies took action in helping those in need. In the twentieth century, the Poor Laws were replaced by the National Insurance Acts (1911, 1946), which provided, among other things, general health care and unemployment benefits on a national level. The Crown hence began to take more responsibility for the quality of life of all citizens, the acts ensuring better political rights, wellbeing and other civil rights. 
The collocates for person reveal specific social groups addressed in the statutes. Many of the improvements concern children, as they are provided with nurturing and education, illustrated, for example, by the collocates education and young (person). In addition to children, the social groups of women, slaves, masters, landlords and vagabonds appear among the collocates of the nineteenth century and in particular the role of children and women are discussed more frequently in the twentieth century. In general, the citizens are portrayed in a more active role in twentieth-century society, with increasing rights to wellbeing and equality. The developments in the semantic preference and semantic prosody reflect the changes made in the status of the social groups through legislation, i.e. many acts were enacted in the twentieth century that specifically enhanced the rights of children and women, for instance, and improved the working conditions, public health and habitation of the citizens (see Section 1).

Another large-scale development concerns changes in legal writing. Collocates that refer to legal language become more common in the latter century since the acts depend on more careful numbering and referencing. The detailed structure and numbered sections enable the texts to make exact references to specific subsections and points in the documents. The development towards careful structuring was gradual: acts from the early modern era did not yet use numbering but relied only on other visual cues including paragraph changes, paragraph marks and gaps in the running text 
(Lehto 2015). Tabulation and numbering started to develop after the early modern era; at the same time, a more distinct structure developed, e.g. the acts in the data of my study contain separate sections in which the terminology used in the acts is explained, while these sections are not found in the acts of the sixteenth or seventeenth centuries (see Lehto 2015). The collocates that denote legal language illustrate the long history of legal writing on another level as well: many acts were amended numerous times, e.g. acts on child labour were repeatedly modified, as the idea of childhood developed and children were provided with schooling instead of work. The amended acts on the same topic make various references to previous legislation, which increases the number of intertextual links. At the same time as the textual links increase, collocates that refer to the authorities decline; the actions of the citizens are increasingly controlled by referring to legal documents and processes instead of naming responsible authorities.

The role of the monarch differs considerably from the representation of the citizens. The authority of the monarch is emphasised, and diachronically the Crown is a much more central figure in the nineteenthcentury acts than in the later documents. The early acts express their admiration of the majesty more often, and formulaic expressions have emerged to express this loyalty (e.g. Honour and Dignity of the Crown). Additionally, the nineteenth-century acts calculate time in relation to the 
ruling years of the king or queen, strengthening the central position of the rulers; in contrast, this practice is not found in the twentieth century. A further strategy to increase the authority of the monarch is established through the topic of possessions, which is a common theme in the earlier acts. The documents refer, for instance, to the lands of the monarch, and there are references to the citizens as possession. The expression majesty's subject(s), for instance, appears in the nineteenth-century acts, but this word string is replaced by the phrase British subject(s) in the twentieth century. The idea of the nation-state becomes more central and replaces the personal references to the king or queen. This development can also reflect changes in legal writing, which became more impersonal and less situation-dependent towards the twentieth century (see Biber 1995: 297). In the twentieth century, the representation of the monarch has diminished, i.e. the monarch is mentioned in formulaic constructions that establish the legal power of the acts. Thus, the monarch can be related with the semantic prosody of power and authority, but this prosody is less elaborate in the twentieth century than in the earlier era.

The semantic prosodies can be evaluated both on the positivenegative dichotomy and also by other uses of the headwords in context. Sinclair (2004) attaches various functions to semantic prosody, such as trouble, in addition to merely evaluating the prosody as negative or positive. Similar conclusions have been made in my study, as the semantic 
prosody of person has been associated with trouble in the nineteenth century and wellbeing in the twentieth century. These prosodies emerge from a pragmatic analysis of the headwords within the textual context of the node. At the same time, the prosodies express positive and negative attributes, i.e. crimes attract negative associations, while wellbeing expresses a more positive view of the role of citizens in society. The analysis has further extended the evaluation of semantic prosody to the socio-historical context, i.e. the associations are interpreted within changes made to legislation which affected people's lives during the nineteenth and twentieth centuries.

The semantic prosodies are genre-specific but they can spread to other genres. The representations of the citizens and authorities recognised in the acts only illuminate their portrayals in one genre. However, the semantic prosodies found in the data can be expected to reflect discourses related to the citizens and authorities on a more general level in the nation. In addition to repeating existing values in society, the acts can even change attitudes towards social groups, as they can alter the legal rights of people. These portrayals can enter other genres in which the social groups are considered, e.g. newspapers report on changes to legislation and can repeat the contents and even exact wordings of the legal documents. Many wordings as well as semantic preferences and prosodies in the acts can further stem from previous political discussions in the Parliament. Baker \& 
McEnery (2005) notice differences and similarities within two genres that discuss refugees and asylum seekers; they point out that the discourse in newspapers links negative attributes to the analysed social groups, while their representation is more positive in texts by the Office of the United Nations High Commissioner for Refugees, but negative portrayals are also found. Baker \& McEnery note that the dominant discourse in the newspapers is difficult to avoid in other genres and the portrayals easily spread to other genres. In the late modern period, legislation became an important tool in improving the living conditions of different social groups, and this more positive view of the citizens in the prestige documents likely extended to other genres. The collocates referring to the topic of legal writing nevertheless also indicate that many collocates are more firmly related to the writing conventions of the genre. The acts include many numbers and formulaic expressions that emerge among the collocates and these expressions are more unique to the legal register.

The study encompassed a relatively large collection of historical acts in a corpus format. The analysis of semantic preference and semantic prosody requires enough data to reveal shared beliefs about groups of people. This method assesses the portrayals on a general level, as the purpose is not to investigate individual texts. For this reason, the semantic prosodies and preferences found in this study are generalisations on the social roles of the citizens and authorities. Further studies could divide the 
material into 25 or 50 -year time periods to allow more detailed analysis of seasonal, terminating and initiating collocates. The collocate discrimination, for instance, emerges in the corpus in the middle of the twentieth century. The most important changes discovered in the collocates, however, seem to occur around the turn of the twentieth century or at the very beginning of the twentieth century. The analysis could be further extended to other genres in order to find out whether the representations differ considerably in genres such as newspapers, political speeches or even in personal correspondence. The study has generally illustrated that the social roles of the citizens and the monarchy are very different in the acts and show many diachronic changes, the citizens gaining novel rights in society. 


\section{Acknowledgement}

This study was supported by a grant from the Emil Aaltonen Foundation (grant number 160143 NIV).

\section{References}

Anthony, Laurence. 2014. AntConc. Computer software. Tokyo, Japan: Waseda University. <www.laurenceanthony.net>

Bäcklund, Ingegerd. 2006. Modifiers describing men and women in nineteenth-century English. In Nineteenth-century English: Stability and Change, Merja Kytö, Mats Rydén \& Erik Smitterberg (eds.), 17-55. Cambridge: Cambridge University Press.

Baker, Paul. 2014. Using Corpora to Analyze Gender. London: Bloomsbury.

Baker, Paul. 2016. The shapes of collocation. International Journal of Corpus Linguistics 21(2): 139-164.

Baker, Paul \& Tony McEnery. 2005. A corpus-based approach to discourses of refugees and asylum seekers in UN and newspaper texts. Journal of Language and Politics 4(2): 197-226.

Biber, Douglas. 1995. Dimensions of Register Variation: A CrossLinguistic Comparison. Cambridge: Cambridge University Press. 
Burr, Vivien. 2002. The Person in Social Psychology. New York: Psychology Press.

Cornish, William, J. Stuart Anderson, Ray Cocks, Michael Lobban, Patrick Polden \& Keith Smith. 2010. The Oxford History of the Laws of England, 1820-1914. Vols. 11 and 13. Oxford: Oxford University Press.

Corpus of Late Modern English Statutes. 2017. Unpublished corpus. Compiled by Anu Lehto. University of Helsinki.

Croft, William. 2000. Explaining Language Change: An Evolutionary Approach. London: Longman.

Fairclough, Norman. 1992. Discourse and Social Change. Cambridge: Polity Press.

Gabrielatos, Costas \& Paul Baker. 2008. Fleeing, sneaking, flooding: A corpus analysis of discursive constructions of refugees and asylum Seekers in the UK press, 1996-2005. Journal of English Linguistics 36(1): 5-38.

Gries, Stefan Th. 2013. 50-something years of work on collocations: What is or should be next... International Journal of Corpus Linguistics 18(1): $137-166$.

Gupta, Kat. 2015. The Representation of the British Suffrage Movement. London: Bloomsbury. 
Hoey, Michael. 2005. Lexical Priming: A New Theory of Words and Language. New York: Routledge.

Hunston, Susan. 2007. Semantic prosody revisited. International Journal of Corpus Linguistics 12(2): 249-268.

Jacobs, Andreas \& Andreas H. Jucker. 1995. The Historical perspective in pragmatics. In Historical Pragmatics: Pragmatic Developments in the History of English, Jucker, Andreas H. (ed.), 3-33. Amsterdam \& Philadelphia: John Benjamins.

Kirby, Peter. 2003. Child Labour in Britain, 1750-1870. New York: Palgrave.

Lehto, Anu. 2015. The Genre of Early Modern English Statutes: Complexity in Historical Legal Language. Helsinki: Société Néophilologique de Helsinki.

Lehto, Anu. 2017. Binomials and multinomials in Early Modern English Parliamentary Acts. In Binomials in the History of English: Fixed and Flexible, Joanna Kopaczyk \& Hans Sauer (eds.), 241-260. Cambridge: Cambridge University Press.

McEnery, Tony. Forthcoming. The criminalized poor: Exploring a marginalized group in public discourse in the 17th century. Proceedings of From Data to Evidence Conference (d2e). Research Unit for the Study of Variation, Contact and Change in English. University of Helsinki. 
McEnery, Tony \& Andrew Hardie. 2012. Corpus Linguistics: Method, Theory and Practice. Cambridge: Cambridge University Press.

McEnery, Tony, Mark McGlashan \& Robbie Love. 2015. Press and social media reaction to ideologically inspired murder: The case of Lee Rigby. Discourse \& Communication 9(2): 237-259.

McLean, Janet. 2012. Searching for the State in British Legal Thought: Competing Conceptions of the Public Sphere. Cambridge: Cambridge University Press.

National Archives of Britain. Acts of Parliament. <www.legislation.gov.uk>

Norberg, Cathrine. 2016. Naughty boys and sexy girls: The representation of young individuals in a web-based corpus of English. Journal of English Linguistics 44(4): 291-317.

Pahta, Päivi, Minna Nevala, Arja Nurmi \& Minna Palander-Collin (eds.). 2010. Social Roles and Language Practices in Late Modern English. Amsterdam \& Philadelphia: John Benjamins.

Partington, Alan. 2004. "Utterly content in each other's company": Semantic prosody and semantic preference. International Journal of Corpus Linguistics 9(1): 131-156.

Pearce, Michael. 2008. Investigating the collocational behaviour of man and woman in the BNC using Sketch Engine. Corpora 3(1): 1-29. 
Rees, Rosemary. 2001. Poverty and Public Health: 1815-1948. Oxford: Heinemann.

Sigley, Robert \& Janet Holmes. 2002. Looking at girls in corpora of English. Journal of English Linguistics 30(2): 138-157.

Sinclair, John. 1991. Corpus, Concordance, Collocation. Oxford: Oxford University Press.

Sinclair, John. 2004. Trust the Text: Language, Corpus and Discourse. London: Routledge.

Sinclair, John, Susan Jones \& Robert Daley. 2004. English Collocation Studies: The OSTI Report. Ed. Ramesh Krishnamurthy. London: Continuum.

Stubbs, Michael. 2001. Words and Phrases: Corpus Studies of Lexical Semantics. Oxford: Blackwell.

Stubbs, Michael. 2002. Two quantitative methods of studying phraseology in English. International Journal of Corpus Linguistics 7(2): 215244.

Sveen, Hanna Andersdotter. 2010. Good-natured fellows and poor mothers: Defining social roles in British nineteenth-century children's literature. In Päivi Pahta, Minna Nevala, Arja Nurmi \& Minna Palander-Collin (eds.), 211-228.

Taavitsainen, Irma. 2015. Genre dynamics in the history of English. In The Cambridge Handbook of English Historical Linguistics, Merja Kytö 
\& Päivi Pahta (eds.), 256-270. Cambridge: Cambridge University Press.

Taavitsainen, Irma \& Susan Fitzmaurice. 2007. What it is and how to do it. In Methods in Historical Pragmatics, Susan M. Fitzmaurice \& Irma Taavitsainen (eds.), 11-36. Berlin: Walter de Gruyter.

Taavitsainen, Irma \& Andreas H. Jucker. 2010. Trends and developments in historical pragmatics. In Historical Pragmatics, Andreas $\mathrm{H}$. Jucker \& Irma Taavitsainen (eds.), 3-30. Berlin: Walter de Gruyter.

Taavitsainen, Irma \& Andreas H. Jucker. 2015. Twenty years of historical pragmatics: Origins, developments and changing thought styles. Journal of Historical Pragmatics 16(1): 1-24.

Thane, Pat. 2010. Women and political participation in England, 19181970. In Women and Citizenship in Britain and Ireland in the 20th Century: What Difference did the Vote Make?, Esther Breitenbach \& Pat Thane (eds.), 11-28. London: Continuum.

Xiao, Richard. 2015. Collocation. In The Cambridge Handbook of English Corpus Linguistics, Douglas Biber \& Randi Reppen (eds.), 106-124. Cambridge: Cambridge University Press. 